\title{
Alaska Resources Library and Information Services: Pioneering Partnerships on the Last Frontier
}

Daria O. Carle

Science Librarian / ARLIS Reference Librarian / Assistant Professor

Consortium Library

University of Alaska Anchorage

3211 Providence Drive

Anchorage, Alaska 99508

Phone: (907) 786-1869

Email: afdoc@uaa.alaska.edu

Juli Braund-Allen

AEIDC Program Manager / ARLIS Management Team Librarian / Associate Professor

Environment and Natural Resources Institute / ARLIS / Consortium Library

University of Alaska Anchorage

707 A Street

Anchorage, Alaska 99501

Phone: (907) 257-2733

Email: anjb1@uaa.alaska.edu 
The $49^{\text {th }}$ State prides itself on its rich history of pioneering spirit, and a unique and innovative partnership that formed ARLIS—-the Alaska Resources and Library Information Services—is a perfect example of this hardy, can-do attitude. Located in Anchorage, the state's largest city, ARLIS is a special library that serves a clientele of federal, state, university, and public users, and is funded by a coalition of federal and state natural resources management agencies and the University of Alaska Anchorage (UAA). Its mission recognizes that improved understanding of Alaska's resources facilitates wise use; to this end, ARLIS strives to provide universal access to natural and cultural resources information relating to Alaska and arctic regions. The library offers a large and unique collection, as well as valuable research and reference expertise to serve the diverse information needs of its patrons in an unbiased and effective manner. Closely aligned with an academic library, UAA's Consortium Library, ${ }^{1}$ ARLIS is nonetheless a separate entity, whose board of directors, and management, budget, and funding structures differ greatly from those of any other library, be it special, academic, school or public. This article chronicles the unusual history of ARLIS and the innovative ways its librarians and partners solved the hurdles they encountered in establishing and operating the library. The authors also discuss some of the new challenges, both physical and philosophical, that ARLIS faces as it prepares to relocate into a facility it will share with the Consortium Library on the main campus of UAA.

Since it opened six years ago, ARLIS has compiled some impressive awards at both state and national levels. The library:

- Received a Legislative Citation from the State of Alaska in May 2002 in recognition of its contributions and service to the people of Alaska.

\footnotetext{
${ }^{1}$ The Consortium Library is open to the public and serves both UAA with approximately 9,500 FTE students, and Alaska Pacific University, a private institution with 500 FTE students. In addition to the main campus in Anchorage, UAA includes four extended colleges and nine additional extension sites on military installations and in rural communities throughout southcentral Alaska.
} 
- Was chosen as one of only three recipients of the 2001 National Awards for Library Service by the Institute of Museum and Library Services, and received the award in a White House Ceremony hosted by First Lady (and librarian) Laura Bush.

- Was honored with the Hammer Award in 1997 from former Vice President Al Gore for its participation in the National Partnership for Reinventing Government Program, one of 1,200 awards presented to teams of federal employees and their partners for innovative efforts to support a government that works better and costs less.

Highlights of recent accomplishments include:

- Gaining a 2003 federal appropriation of nearly $\$ 500,000$ to catalog and provide access to a backlog of approximately 180,000 items, including unique documents of critical importance to natural resources decision-making. A portion of the money will be used to digitize and make web-accessible a significant collection of environmental baseline reports.

- Participating in the local online catalog that also serves UAA and its extended campuses, the Alaska Pacific University, the Municipality of Anchorage's main public library and five branches, and the Anchorage Museum of History and Art.

- Cooperating in the borrowing agreement established in 2000 among the local online catalog participants. The agreement enables patrons with a card at one library to use that card to borrow materials from any participating library, as well as to return books to any of them. It also reduces the number of patrons each library must register and allows information about delinquent patrons to be shared.

- Receiving nearly $\$ 90,000$ in grants from the Alaska State Library over a period of two years to catalog and link 5,000 web documents about Alaska and arctic-related materials in both OCLC and the local online catalog. 
- Sharing a University of Alaska grant that funded the cataloging of one-of-a-kind documents and reports from one oil company and two state agencies whose libraries had either closed or were being dismantled.

Why is ARLIS so special?

"ARLIS is a national treasure," according to Peter Wilkness, former director of polar programs for the National Science Foundation. The library is valuable, Wilkness points out, because it includes rare and unique federal documents, pre-statehood publications, industry materials side-by-side with government materials, and many different scientific disciplines about Alaska, all in the same place (Friends of ARLIS 2002). Often referred to as the "mother lode of Alaska resources information," ARLIS collects and disseminates information that supports the conservation, management, and development of Alaska's natural and cultural resources.

Gathered over many decades in an effort to preserve historical information and provide contemporary scientific literature to support current research, the collection emphasizes all aspects of Alaska and northern regions: ecology and habitat, fish and wildlife, geology and mining, oil and gas, climate and cold weather engineering, water resources and hazardous waste, and subsistence and historic preservation. ARLIS also has an extensive journal and multimedia collection, a large cache of report literature drawn from public and private sectors, and baseline data of past oil and gas development.

"ARLIS is now the premier natural resource collection in the state, bar none" (Dunn and Malyshev 2002, 3). Much of the collection is unique to Alaska, especially the ephemeral material of gray literature: in-house reports, agency documents, and other items with extremely 
limited distribution. This hard-to-find material, and often the only copy available, contains valuable information that quickly becomes irretrievable unless it is collected and cataloged.

ARLIS' users are diverse and include the business and legal communities, environmental groups and consultants, Alaska Native corporations, the petroleum industry, miners, educators, and students, as well as other libraries, locally and internationally. Many of ARLIS' clientele have sophisticated research needs, but live and work in remote parts of the state with nonexistent or inadequate local libraries. Through the depth of its collection and an intensive document delivery service, ARLIS provides access to the professional literature that users need to do their jobs, whether in the field, remote office, or city. In 1999, ARLIS established a presence on the Internet (http://www.arlis.org). Its website features $24 / 7$ access to the shared online catalog as well as information about ARLIS, its collections and services, reference assistance, and links to other relevant sites.

ARLIS' most valuable asset is its knowledgeable staff. To quote one enthusiastic user, "the collective experience of the librarians is awesome" (Dunn and Malyshev 2002, 3). Responding to inquiries on-site, by telephone, mail, email, or fax, ARLIS librarians provide unbiased access to information to patrons on all sides of the issues, in Alaska, nationwide, and around the world. Public service statistics, including numbers for interlibrary loan, circulation, and reference, have continued to increase every year ARLIS has been open. In 2002, ARLIS had some 20,000 onsite users and answered more than 30,000 requests for information; half of these were public users (Holba 2003).

As part of its citizen-centered approach to library service, ARLIS provides a conference room where parties from different sides of an issue can meet on neutral ground. Front-page news about decisions on controversial topics such as wolf management is often decided here, as the 
many perspectives of resource conservation and development are discussed. The conference room also draws additional patrons into the library who may not have been aware that a place like ARLIS existed.

One of the most unique items at ARLIS is the collection of furs, skulls, and bird mounts donated by the Alaska Department of Fish and Game. Consistently one of the most popular and heavily used collections, the materials are searchable in the online catalog and circulate like books to patrons. Elementary schoolteachers, scout leaders, wildlife artists, and various other parties doing outreach activities and environmental awareness find the specimens to be an invaluable source for hands-on education.

The Alaska Department of Fish and Game also contributed a unique collection of pre- and poststatehood reports from their Commercial Fisheries Division. The collection documents statewide use of fishery resources, management decisions, and life histories of fish species from a regional perspective. Because fluctuating fish harvests significantly impact both economics and ecosystems on a local, regional, and global scale, this information is of critical importance to the fishing industry, the environmental community, and those who depend on fish resources for their livelihood.

New materials from a variety of sources continue to be added to ARLIS' holdings. The literature cited in the environmental report for the right-of-way renewal of the Trans-Alaska Pipeline System, and a major collection of aerial photographs from the Alaska Department of Natural Resources are examples of two recent acquisitions. Over the past several years, collections of professional-level materials on bears, moose, and mushrooms were donated to ARLIS from specialists in these fields. Documents for public comment and review from government agencies, military installations, consulting firms, and other organizations are also housed at 
ARLIS, providing a location in the community where these documents are available for interested parties to read.

ARLIS is involved in a number of new programs and cooperative partnerships that help further its viability. It is currently participating in a Virtual Reference Service pilot project in conjunction with other public and academic libraries around the state. ARLIS also contributes data to Alaska's Cooperatively Implemented Information Management System, a web-based tool (http://info.dec.state.ak.us/ciimms) that helps users find tabular and geo-spatial information about Alaska's ecology and natural resources.

In another joint venture, ARLIS partnered with state and federal geology agencies and groups with mining-related concerns, including the Alaska Miners Association and several minerals exploration companies, to make Alaska minerals information available to the public. This program, called Minerals at Risk and funded by the U.S. Congress, approaches informationseeking from a miner's point of view and simplifies access by providing the data in web-based format. Their publication, Guide to Alaska Geologic and Mineral Information (http://www.dggs.dnr.state.ak.us/Libguide/Section1.htm), identifies sources of published and unpublished information about geology, mining, and mineral exploration in Alaska. With financial support from this program plus additional funding from federal geological agencies, ARLIS is cataloging all of its geology-related collections. In addition, ARLIS is providing an online index to an extensive collection of maps, files, field notes, and reports developed by Anaconda, a commercial mining company, and donated to the library by Cook Inlet Region, Inc., one of Alaska's 13 Native regional corporations.

How did ARLIS come about? 
In a letter of support for ARLIS, Fran Ulmer, Alaska's former Lieutenant Governor, wrote: "ARLIS is an excellent example of city, state, university, and federal government reaching across agency boundaries to make resources available to the widest constituency" (Friends of ARLIS 2002).

At the very heart of ARLIS is a collaborative and innovative partnership that was carefully crafted and implemented over time. It began as a ground swell by librarians and library users, gained the support of top management, and today has become a model of success for multiagency cooperation. The library opened its doors in Anchorage in the fall of 1997, but had been conceived several years earlier in response to serious economic pressures. In the late 1980s and early 1990s, when Alaska's oil boom had collapsed and the state was mired in financial woes, national downsizing and budget constraints tightened the squeeze. By the mid-1990s, many of the libraries of the natural and cultural resources agencies at the university, state, and federal levels had experienced or were facing budget cuts, loss of personnel, and/or outright closure. Some agencies were considering sending their collections to regional offices in Washington or Oregon, or even as far away as Washington, D.C. Because Alaska's economy is largely based on natural resources, it relies on these agencies for forming the conservation and management policies for its planning and development. The loss of the libraries and collections that support these efforts was seen as a catastrophic blow-not just for agency personnel but also for all Alaskans.

Alaska has always been a "book poor" state with few funding dollars and a small population scattered across a vast geographic expanse (Braund-Allen 1997), so cooperation among its libraries and librarians is extremely important. Over the years, librarians had worked out, both formally and informally, which libraries would collect what, so that one library would have a more 
complete collection in one area, allowing another library to collect more extensively in another. Public, special, academic, and school, as well as many state and federal libraries all participated, each relying on the other to create a broader and more in-depth collection than otherwise would have been possible. Because of this closely knit collecting and borrowing, decreased access to or closure of any library would significantly diminish Alaska's information base. As for the agency collections, no resources existed anywhere else in the world to replace what would be lost if even one of the libraries containing this material closed.

Thus it was with renewed and pressing interests that the librarians from these agencies began meeting weekly to brainstorm what they could do to salvage not only their libraries but, most importantly, in-state access to their collections. Through these meetings, the librarians reached the conclusion that combining forces to create a new library was the best course of action. Reasons for a consolidated library were many, but fundamentally, the goals were to: enhance services; be open to the public; serve the information needs of agency personnel; keep the collections in Alaska, and preserve and provide access to them; give users "one-stop shopping" by having the materials in a single place rather than scattered in individual libraries across the city; and ultimately save money by consolidating services and overhead.

The original partners, all located in Anchorage, included five federal agencies, one state agency, one joint federal-state entity, and one university. The five federal agencies represented the libraries from the Alaska regional offices of the U.S. Bureau of Land Management, the U.S. Fish and Wildlife Service, the U.S. Geological Survey, the U.S. National Park Service, and the U.S. Minerals Management Service. The Habitat Library from the Alaska Department of Fish and Game and the Oil Spill Public Information Center from the Exxon Valdez Oil Spill Trustee 
Council $^{2}$ comprised the state and joint federal-state agencies. The university partner was represented by UAA, including the Consortium Library and the Environment and Natural Resources Institute's Arctic Environmental Information and Data Center.

The librarians knew they would require support from the top level of their respective administrations to make a combined library succeed, and to gain this they needed to organize their efforts and gather data. They formed the Alaska Natural Resources Library Group (ANRLG), adding a librarian from the public library as well as a federal researcher to ensure additional user perspectives. Sponsored by the Department of the Interior, ANRLG applied for and was granted Reinvention Laboratory status under then-Vice President Al Gore's Reinventing America Program. ANRLG went through intense formal team training, which reinforced the need to focus on the patron-a concept that comes naturally to librarians. An initial step in the process was to scan the literature for examples to use as models for the partnership structure of their proposed library. While none existed, ANRLG did glean some cautionary advice from others whose similar attempts at various types of consolidations had failed.

ANRLG also conducted focus groups and informal surveys to determine what services and issues were important to their users (ANRLG 1997, 14). The focus groups were organized by patron type: state or federal agency personnel working in Anchorage or in remote locations; UAA faculty, researchers, and students; miners and others engaged in small industry; nonprofit users and organizations; and for-profit users and businesses. Members of each group were asked how they used the libraries, what aspects of the current arrangement were not working

\footnotetext{
${ }^{2}$ The Trustee Council is composed of three federal and three state representatives, whose charge is to administer the civil settlement funds from the Exxon Valdez oil spill litigation. Specifically, the funds are used for activities to restore damaged resources and resourcedependent services in the spill area, acquire and protect spill habitat, and support scientific research and a public information center.
} 
for them, and how they would like to see a consolidated library operate. Certain groups (small industry, nonprofit, and for-profit users) were also asked what library services they would be willing to pay for and how much they would be willing to pay.

The main survey tool used was based on a Canadian study in a Special Libraries Association publication that analyzed how to quantitatively and qualitatively measure the effect of library use on corporate decision-making (Marshall 1993). The survey had originally focused on special libraries serving financial institutions, but was modified to fit the needs of ANRLG and distributed during the spring of 1996 to users of state- and federally funded resources libraries in Anchorage. Those surveyed included state and federal agency personnel; UAA faculty, researchers, and students; and the patrons of the Oil Spill Public Information Center. (See Appendix.)

Data gathered from the focus groups and survey showed strong use of Anchorage-based resource libraries by all patrons. All users supported the idea of a consolidated library that was centrally located and easily accessible with adequate parking. Most wanted expanded services, such as electronic access to collections and increased access to more databases. All stressed the importance of retaining the collections, as well as the services and expertise of the agency librarians and staff. Ninety percent of survey respondents said they needed information from a library in order to perform their job. One user wrote: "One of the criteria I evaluated when I considered taking the job here in Alaska ... was if reference material was readily accessible. As a scientist/manager it is essential to remain current in the scientific literature and to do so requires the assistance of a quality library and its associated staff in close proximity." Another wrote that the cost of doing business would increase "if we had to send staff to libraries 'Outside' [Alaska] to conduct research which is part of our day-to-day business." Still another said: "I don't think the issue is so much time and money as it is completeness and coming up 
with the best information to make decisions about techniques and impacts to protect the land" (ANRLG 1997, 19).

After reviewing the data, the librarians considered the many valid concerns their users had raised, including how the costs of a consolidated library could be shared equitably, what the effect of not having a library located in the same building might have on work productivity, and how services might be increased while spending less money. Taking these issues into account, the librarians put together a careful campaign to sell the idea of a consolidated library. They had been advised during the Reinvention Laboratory process to "follow the money" when considering who they should approach for support. This meant appealing to those who would be funding the project-the top administrators in each of their agencies and organizations (Braund-Allen and Sokolov 1999). The librarians detailed the services the proposed library could offer and listed its advantages for the agencies, the public at large, and the state. They made a separate list of the consequences library closures and lost collections would have on research and, ultimately, on the state's ability to make wise and balanced decisions. They drew up a preliminary partnership and management structure, as well as a rudimentary library organization plan and budget. The librarians put together their package, and, in groups of two and three, met with top agency administrators, almost all of whom recognized the importance of the information in these libraries and quickly agreed to support the proposal. As part of the Reinvention Laboratory process, the administrators formed a Management Advisory Group, whose role, politically, and especially financially, was to ensure that the library would become a reality. These were people in influential positions with the authority to see this project through.

In general, federal administration of Alaska's natural and cultural resource agencies is handled regionally, rather than through a statewide or multi-state office, due in part to the state's remoteness and geographic scale; at more than 365 million acres, Alaska is larger than 
California, Montana, and Texas combined. (See Figure 1.) As a result, the federal players in ARLIS' partnership were highly placed individuals in their respective agencies and administrations. They included, for example, the U.S. Department of Interior's Special Assistant to the Secretary for Alaska and the Alaska State Director of the Bureau of Land Management, as well as the Regional Directors of the U.S. Minerals Management Service and the U.S. Fish and Wildlife Service. Other members were also those at the very top, including the Commissioner of the Alaska Department of Fish and Game and the Chancellor of UAA.

Even with the active involvement and strong support of their agency heads, and aided by the long-term assistance and advice of consultants provided through the Reinvention Laboratory process, the librarians found their task daunting. They needed to detail a plan that would address the infinite details involved in merging not only eight library collections, but also eight individual libraries. Complicating this was the fact that many of the libraries had been oneperson operations, whose librarians were accustomed to tailoring services to meet the needs of their particular agency and its users. Moreover, the librarians had decided from the beginning to make all decisions by consensus. This was done to ensure that the needs of each agency would be addressed, but in reality, using consensus often meant that a satisfactory solution could only be achieved after deliberating over a difficult issue, leaving it to rest, and then revisiting it again and again.

The librarians met weekly for nearly two years, all the while maintaining limited services in their libraries or, for those whose libraries had closed, working on other projects. During this time, they painstakingly mapped out a viable method to deal with agencies with different missions, different fiscal years, different reporting structures, different procurement methods, and different personnel policies, procedures, and holidays. In addition, they had to address the conflicts 
inherent in having different clientele, different levels of service, and different approaches to library acquisitions, circulation, and cataloging (Carle and Braund-Allen 2002).

Along the way, the librarians also measured the existing collections for the new library's spatial needs. They plotted how many people and what types of positions would be needed to operate the library when it opened. They debated how many copies of an item they might need, and what would happen if an agency researcher needed a source that was checked out to a public patron or a student. They drew up budget after budget, and realized that any projected costsavings would not accrue for some time, at least until after the initial outlays for establishing ARLIS had been paid. They determined how they could most advantageously pool existing resources and staff, and what a fair monetary or in-kind share would be for each of the founding agencies to contribute annually. They discussed differing levels of service and how those levels might relate to annual contributions. They devised an organizational structure that allowed future partners. They brainstormed innovative fee-based services that would help support the new library. They learned that federal libraries could not collect fees for service, but that state and university libraries could. Gradually over time, a workable library structure emerged that could meet a host of varying needs while still providing exemplary service to users (BraundAllen and Carle 2002).

How did the agencies form ARLIS?

While working out the details of creating ARLIS, the librarians met intermittently with federal, state, and university attorneys to make sure that what they were attempting was possible. Conversations about how the library partnership could be realized had flown back and forth for several years among the librarians, their Reinvention Laboratory advisors, and the Management 
Advisory Group. Now, with all the planning done, it was time to formalize the legal details. The structure for operating ARLIS and for establishing the partnership among the founding agencies that would support it was ultimately charted through a series of documents (ANRLG Reinvention Laboratory 1997).

The first of these documents was a Memorandum of Understanding (MOU), which stated the intent in establishing ARLIS and cited the legal authority by which it could be done. The MOU gave the conceptual framework for the library's administration, including the guiding principles and responsibilities of all participants. It described the organizational structure among the agencies for operating ARLIS, as well as provisions for adding new partners and for withdrawing from the partnership.

The MOU affirmed free public access to its collections, including use by private consultants and staff of government agencies not directly supporting ARLIS. For those who contributed financially, the MOU defined the funding commitments required for two levels of membership: participants and founders. The annual minimum needed to qualify as a participant was set at $\$ 5,000$ and could be negotiated upward for customized levels of service. The specific services a participant received would depend upon its needs and the amount of funding it contributed.

An agency could become a founder by contributing funds commensurate with its size and projected library use. Founders would receive unlimited check-out of materials; extensive reference and research support, including literature searches; interlibrary loan and desktop document delivery services; desktop electronic access to databases and journals; and free copying. A yearly minimum of $\$ 40,000$ was established for a small organization, while larger ones gave anywhere from $\$ 70,000$ to more than $\$ 500,000$ annually. Many founding agencies 
included the time of their staff librarian and other personnel as an in-kind contribution to ARLIS; equipment, supplies, services, and other items also counted as in-kind support.

The amount needed for an agency to be considered a founder was calculated by determining the cost of operating a one-person library. This figure was modified according to agency size and an estimated research-to-employee ratio. The projected cost of opening and operating ARLIS was also factored in, as was the expense involved in merging the collections. The latter cost was borne proportionately by the agencies, so that an agency with a large collection paid more than another with only a small collection.

The MOU also specified that a Founders Board be appointed to govern the library. The Board would be composed of administrators of the founding agencies or their designated representatives, and was to meet at least twice yearly. Its responsibilities included exercising budget authority, making upper-agency management decisions, adopting policies, and ensuring the viability of ARLIS. The members of the Founders Board were, for the most part, the same people who had served ARLIS so well as its Management Advisory Group under the Reinvention Laboratory process. (Alaska law precluded ARLIS' sole state partner from giving the Founders Board any binding authority over state policies, property, or resources. Because of this, the Alaska Department of Fish and Game entered into a separate contractual agreement that affirmed its participation in ARLIS but recognized the authority of the Founders Board as purely advisory.)

The MOU outlined how the contributions would be gathered and expended, and designated UAA as ARLIS' administrator for the partnership. To effect this arrangement, the five federal Department of Interior agencies first entered into an intra-agency agreement that spelled out what each would contribute to ARLIS in terms of personnel, cash, services, collections, 
equipment, and furniture. This intra-agency agreement designated the Bureau of Land Management as the agency responsible for collecting and dispensing federal funding for ARLIS. Then the agencies, together with the Exxon Valdez Oil Spill Trustee Council, entered into an assistance agreement with UAA. This agreement enabled them to pay their shares for the operation of ARLIS to UAA.

As part of its share as outlined in the assistance agreement, UAA was charged with: providing space to house the ARLIS collection; acting as hiring agent for personnel; serving as purchasing agent for books, journals, and necessary supplies; contracting for bibliographic and online services; supplying in-kind librarian and technical support services; and performing general procurement and management tasks. UAA was also responsible for budgeting and day-to-day financial matters relating to any cost overruns. If the latter seemed likely, UAA was tasked with notifying the Founders Board, which in turn would decide upon a course of action. UAA also contributed a library collection-the Arctic Environmental Information and Data Center-from one of its research institutes, along with the part-time services of the Center's librarian and library assistant.

As the lead agent designated in the assistance agreement, the Bureau of Land Management agreed to provide: staff, including librarians and library technicians, who would remain in the employ of their respective agencies; the agencies' library collections of books and journals; and the computers, equipment, and supplies that had been part of the agencies' libraries. The Alaska Department of Fish and Game, again through a separate agreement, contributed the collection and librarian from its Habitat Division Library, as well as cash, in-kind services, and supplies. 
How is ARLIS managed?

Just as the librarians used consensus in the planning process to ensure that each agency voice would be heard, they also decided that team- and consensus-based management would apply once the library opened. Instead of having one director, the library would be guided by an ARLIS Management Team with a collective voice and the collective responsibility of leadership. Participation fluctuated at first, but the Team was ultimately composed of six of the librarians from ANRLG whose collections had been transferred to ARLIS. Some also took on the responsibility to act as library representatives for two of the founding agencies that had contributed collections but not staff, the National Park Service and the U.S. Geological Survey. (See Figure 2.) Management Team librarians continued to spend time at their agencies each week, enabling them to stay in tune with agency needs, perspectives, and current research topics. More importantly, the librarians provided an ARLIS presence within their agency; most researchers were accustomed to having their own library "just down the hall" and appreciated the close contact. This interaction, which helped ease the transition between the closing of the agency libraries and the opening of ARLIS, continues to this day.

Management Team responsibilities include working with the Founders Board by preparing budgets and developing policy for Board approval, conducting long-range planning, identifying potential partners, and responding to requests from and following up on actions by the Board. In addition, the Team directs all aspects of the library, from implementing budgets and policies, to setting priorities and staff allocation, developing protocols and procedures, ensuring administrative controls and accountability, and seeking and administering grants. Team members also oversee the day-to-day operations of ARLIS, and most serve in coordinator roles for Systems, Budget, Reference Services, and Collection Development. 
Management Team librarians have gained valuable perspectives through interactions with and mentorship by the Founders Board. While their ranking within their individual agencies and organizations has, for the most part, remained the same, the Team members' level of responsibility and status has increased not only through their role as the collective director of ARLIS, but also through direct ties to budgetary and policy development. All have grown in their careers through increased familiarity with the methodologies by which upper-level management negotiates and reaches decisions. The extent to which the Founders Board trusts and relies on the Management Team is also a source of professional career satisfaction and personal growth.

How did ARLIS receive a federal appropriation?

From the beginning and as part of its strategic plan, ARLIS had actively sought grants and other sources of funding to make its collections more accessible. The library itself was prohibited from lobbying due to its federal partners, but that did not preclude satisfied users and supporters such as the Friends of ARLIS ${ }^{3}$ from spreading word of its success. ARLIS' rich collections and reputation for excellent service garnered many awards, which brought prominence to the library. Over time this growing recognition helped create a large advocate base for the library.

Since ARLIS' inception, many people in various ways and at many different bureaucratic levels had attempted to gain a standing federal appropriation for ARLIS. A line-item appropriation that would fund staff and day-to-day operations for the federal side of the ARLIS budget has also been one of the Founders Board's ongoing goals. Such an appropriation would provide stability to the budget and simplify long-range planning since ARLIS would no longer have to compete

\footnotetext{
${ }^{3}$ Friends of ARLIS, formed in 2002, is an ad hoc group of for-profit consultants, nonprofit environmental groups, and other parties not affiliated with ARLIS, who seek alternative and creative means of generating income for the library.
} 
with other priorities for annual funding within each agency. Unfortunately, the line-tem appropriation has not yet been passed, although efforts continue to make this happen.

In spring 2003, ARLIS did receive a federal special project appropriation of almost $\$ 500,000$ to start cataloging its backlog and several special collections and to digitize a large series of baseline environmental reports dating back to the early 1970s. ARLIS may never know whoindividually or collectively—was ultimately responsible for what is hoped to be the first installment paid out over the next ten years, but at least three groups and one individual had pivotal roles. The first group, one of the national geological societies, with support from Friends of ARLIS, had met with Alaska's Congressional Delegation to stress the national and economic importance of ARLIS' collections. Another group consisted of Alaska's State Librarian, the Dean of UAA's Consortium Library, and the Director of the Rasmuson Library at the University of Alaska Fairbanks. These three represent the largest libraries in the state, and together they spoke to Alaska's Congressional Delegation on ARLIS' behalf. The Secretary of Interior's Alaska field office gave essential support, as did the senior advisor to the Secretary for Alaska Affairs. Finally, as Chair of the Senate Appropriations Committee, Alaska's senior Senator has long been aware of the importance of ARLIS in managing Alaska's natural resources and lent his support to obtaining the special appropriation (Vitale 2003).

Together, these and many other voices have made it possible for ARLIS to begin work on cataloging and adding to the web-based catalog nearly 180,000 items, more than a third of which are estimated to require original cataloging. The backlog includes many extensive collections of professional materials from individuals and public and private agencies. Examples include the U.S. Federal Power Commission Hearings from the early 1970s on the Alaska Natural Gas Transportation System Project; the Arctic Gas Collection of engineering and environmental reports; a series of documents assessing the development requirements and 
potential environmental impacts of the proposed Susitna Hydroelectric Project in Anchorage's nearby Matanuska-Susitna valley; selected materials from the Alaska Department of Environmental Conservation Library that closed in 1997; and materials dealing with all aspects of oil production from disbanded oil company libraries in Anchorage, including those of Atlantic Richfield and British Petroleum.

The digitizing portion of the project focuses on the Outer Continental Shelf Environmental Assessment Program (OCSEAP) reports funded through the National Oceanographic and Atmospheric Administration from 1975 through 1985. Millions of dollars were spent during OCSEAP to gather baseline data and record the distribution of marine birds and mammals in anticipation of oil development on Alaska's continental shelf. Making this fragile paper collection of comprehensive geographic and environmental data digitally available will provide an especially rich source of information for scientists, researchers, and managers around the world.

To accommodate the additional workload when the project was launched in July 2003, ARLIS hired some 20 temporary library personnel, including catalogers, clerks, students, and reference librarians. Catalogers were hired from a local labor pool and through a national program called ECO, the Environmental Careers Organization (http://www.eco.org/). In existence for more than 30 years, its purpose is to enhance and protect the environment through career opportunities in conservation fields. ECO does this, in part, by offering internships in the public, private, and nonprofit sectors to recent graduates and current undergraduate and graduate students.

ARLIS' five ECO interns from all over the United States are gaining practical job experience and valuable training in cataloging special library materials.

Even while celebrating the beginning of this long-sought project, however, ARLIS realizes it still faces many uncertainties. Alaska's changing political landscape and another looming fiscal 
crisis make for unpredictable times. Already a division of the Alaska Department of Fish and Game that was one of ARLIS' original founders has been dissolved, and other partners are experiencing similar budget shortfalls. While the Alaska Department of Fish and Game funding has been resolved for FY2004, ARLIS' need to find additional partners takes on new urgency. The multi-agency Joint Pipeline Office became a partner early on and the U.S. Army Fort Richardson's Environmental Division joined in 1998. Two more possibilities are the Alaska Department of Natural Resources and the U.S. Forest Service, whose library in Juneau, Alaska, closed during the summer of 2003.

How will moving to the UAA campus affect ARLIS and the Consortium Library?

When ARLIS moves into UAA's library addition in 2004, it will be a special library that shares a facility with an academic library. A similar model currently exists: the Health Sciences Information Services (HSIS) is a medical library contained within and administered by the Consortium Library. HSIS' primary function is to serve healthcare providers throughout the state, as well as the students, staff, and faculty of UAA, particularly those in nursing, allied health, and pre-professional programs. Monies for HSIS' services to students, faculty, and staff come from the State of Alaska through UAA. The remaining funds are generated by organizational contracts and individual fees from healthcare professionals and the general public to provide database searches, interlibrary loans, and document delivery. HSIS' books, cataloged using the National Library of Medicine classification system, are inter-shelved with Consortium Library books; their journals are shelved separately, but fully accessible to all. The perspectives of HSIS' staff and its interactions with the Consortium Library provide helpful insights in how the differing missions and philosophies of a special and an academic library affect day-to-day library operations. 
The co-location will offer ARLIS patrons increased access and convenience to the collections far beyond the Monday through Friday, 40 hours per week schedule ARLIS currently maintains. ARLIS' hours will more than double since its collections will be available all of the hours that the Consortium Library is open. While Consortium Library employees who currently work some varying number of hours at ARLIS will continue to do so, many others have expressed interest in working with ARLIS librarians to learn more about its holdings. ARLIS librarians, in turn, would like to gain a greater understanding of the environmental materials of the Consortium Library, particularly those in the Alaskana, Government Document, and Archives collections. These and many other types of cross-training opportunities will no doubt occur, ultimately benefiting all patrons who access and use the library. Although some interaction currently exists between agency researchers and UAA faculty and scientists, having ARLIS on the main UAA campus will facilitate even more collaboration on research projects and publications. In addition, the Consortium Library's science librarian, who currently works a few hours each week at ARLIS, will be more accessible to ARLIS users. Similarly, the cultural and natural resources expertise of ARLIS librarians will be more available to Consortium Library patrons.

Other major benefits for ARLIS include an appreciable gain in size at a decreased cost; ARLIS will have roughly 30 percent more space, going from 15,000 to 20,000 square feet, and the cost of the space will be considerably less, with ARLIS saving more than $\$ 150,000$ annually compared to the rent it now pays to a landlord in the private sector (Tileston 2003). The increased room will allow ARLIS to feature more prominently some of its northern art, artifacts, and other unique items. Although the same architectural style and materials for information contact points will be used throughout the new library building, displaying these materials in permanent or rotating exhibits will bring a different atmosphere to the area ARLIS will occupy and visually differentiate it from the Consortium Library. 
ARLIS will no longer need to maintain a separate circulation desk since the new facility will have only one circulation point at the exit of the building. The procedural details of sharing a circulation desk have not been determined, but ARLIS is currently color-coding the spines of its books to easily distinguish them from Consortium Library books. This will also simplify reshelving for the student employees. The extended hours of the Consortium Library may offer ARLIS employees the chance to work a more flexible schedule. Other potential benefits could include consolidating some interlibrary loan and technical processing functions. The Joint Library Catalog will not have to be modified because it already includes ARLIS' collections. The difference for Consortium Library patrons will be that the ARLIS book or journal will be available within the shared building rather than in a separate facility down the street. This will be a special boon to users during Alaska's long, dark winter months.

However, many additional issues will need to be resolved, especially since many of the opportunities and pitfalls will only become apparent after the two libraries actually begin to coexist. One known concern is that by being located in the same building as the Consortium Library, ARLIS might appear to be "subsumed" by UAA. Although the collections of the two libraries will be co-located rather than merged, with ARLIS in an area distinct from the rest of the Consortium Library and possessing its own reference desk, offices, conference room, and technical services area, users may perceive ARLIS as simply another collection belonging to the much larger Consortium Library. Even though ARLIS has a completely different mission, purpose, and clientele, the two organizations serve many of the same users. Indeed, Consortium Library users will be encouraged to turn to ARLIS for its unique in-depth environmental information. Consortium Library students and faculty, while strong users of ARLIS now, will be even more so when ARLIS is located on the main campus. 
Another concern is that once ARLIS is on campus, it may be considered to be in a "safe" place where it can be taken care of by the University and no longer in need of funding, personnel, or other financial support from the founding agencies. All those involved with ARLIS share this concern. For its part, the Consortium Library does not have the means, personnel, or intention to take on the added responsibilities of ARLIS. Other issues include the possibility of increased risk to the security of rare items in ARLIS' collection, different policies and procedures that on a practical level may likely collide in daily operations, and the mixed service philosophies and practices of a special and an academic library, whose boundaries may well be blurred to many users. How ARLIS maintains its unique identity as a special library within an academic setting will be a challenge.

What does the future hold?

Now, six years after its 1997 opening, ARLIS is thriving and " . . has succeeded, and even exceeded, its original intent ... " (Dunn and Malyshev 2002, 3). In a stroll through ARLIS, it is possible to encounter middle school students studying oil spills; graduate students analyzing wildlife survey techniques; public patrons interested in mining; agency and academic researchers investigating causes and impacts of melting glaciers; consultants gathering information on Alutiiq culture; an artist painting a still life using a stuffed and mounted loon as a model; and members of the private and public sectors browsing the shelves during a break from a day-long discussion of how to best route the city's proposed coastal trail extension with the least impact to wetlands, existing development, and scenic resources (Braund-Allen and Carle 2002). 
"This collaborative effort offers a range and scope of expertise, services, and resources useful to a wide range of user groups that an individual governmental agency library would be hard pressed to match" (Dunn and Malyshev, 2002, 4). In fact, ARLIS' partnership runs contrary to the popular notion of corporate outsourcing so heavily publicized over the last decade. ARLIS instead promotes a form of "in-sourcing" by fostering an innovative structure that allows the partnership to take advantage of what makes each agency unique. The ultimate goal, and one that has sustained all ARLIS employees, users, founders, and other supporters throughout its creation, development, and implementation, is that everyone wants to see it succeed. If the past is any indication, those involved in ARLIS have the pioneering spirit to ensure its future.

\section{Literature Cited}

Alaska Natural Resources Library Group Reinvention Laboratory. 1997. Interim Report. Anchorage, Alaska.

ARLIS Management Team. 2001. [Nomination for the] 2001 National Award for Library Service, Alaska Resources Library and Information Services. Anchorage, Alaska.

Braund-Allen, Juli. 1997. The Alaska Natural Resources Library Group: Adapt, migrate, or die.

Pages 37-39 in Creativity lighting the poles: Collaborative solutions to common

Formatted

problems: Proceedings of the $16^{\text {th }}$ Polar Libraries Colloquy, June 17-22, 1996,

Formatted

Consortium Library, University of Alaska Anchorage, edited by Juli Braund-Allen and

Cathie Innes-Taylor. Anchorage, Alaska: University of Alaska Anchorage. 
Braund-Allen, Juli, and Barbara Sokolov. 1999. Alaska Resources Library and Information Services. Pages 201-206 in Electronic information and publications: Looking to the electronic future, let's not forget the archival past: Proceedings of the 24th Annual Conference of the International Association of Aquatic and Marine Science Libraries and Information Centers, and the 17th Polar Libraries Colloquy. Joint conference held 20-25 September 1998, Reykjavik, Iceland, edited by James W. Markham, Andrea L. Duda, and Martha Andrews. Fort Pierce, Fla.: IAMSLIC.

Braund-Allen, Juli, and Daria O. Carle. 2002. Alaska Resources Library and Information Services: Building community in the 49th State. Reference \& User Services Quarterly 42(2): 119-123.

Carle, Daria O., and Juli Braund-Allen. 2002. ARLIS: A model for successful partnerships in the online age. Pages 16-22 in Poles apart, poles on-line. Proceedings of the 19th Polar Libraries Colloquy, 17-21 June 2002, edited by Kristin Caning and Vibeke Sloth Jakobsen. Copenhagen: Danish Polar Center Publication no. 10.

Dunn, Sandy, and Nina Malyshev. 2002. Alaska Resources Library and Information Service organizational assessment: Final report and recommendations. Anchorage, Alaska: U.S. Bureau of Land Management and Alaska State Library.

Environmental Careers Organization. 2003. Available: http://www.eco.org/ Accessed 2 June.

Friends of ARLIS. 2002. Fact Sheet. Anchorage, Alaska. 
Holba, Carrie. 2003. Telephone conversation with the authors. Anchorage, Alaska, 13 June.

Marshall, Joanne G. 1993. The impact of the special library on corporate decision-making.

SLA Research Series no. 8. Washington, D.C.: Special Libraries Association.

Tileston, Nancy. 2003. Telephone conversation with the authors. Anchorage, Alaska, 8 August.

Vitale, Cathy. 2003. Telephone conversation with the authors. Anchorage, Alaska, 30 July. 